\title{
EKSISTENSI KREDITOR SEPARATIS SEBAGAI PEMOHON DALAM PERKARA KEPAILITAN
}

\author{
Fani Martiawan Kumara Putra \\ Fakultas Hukum Universitas Wijaya Kusuma Surabaya \\ e-mail: fanimartiawan@gmail.com
}

\begin{abstract}
ABSTRAK
Kepailitan merupakan salah satu jalan keluar yang dapat ditempuh oleh pihak-pihak yang mengadakan hubungan hukum berupa perjanjian utang-piutang. Melalui adanya kepailitan, maka menambah cara penyelesaian sengketa utang-piutang di Indonesia yang mana sebelumnya hanyalah gugatan wanprestasi. Kepailitan sebagai suatu bentuk penyelesaian sengketa yang khas ini merupakan perkembangan dari masa ke masa, sebagaimana terdahulu awal pengaturannya pada Pasal 749-910 Wetboek van Koophandel, hingga pengaturan yang terakhir adalah melalui Undang-Undang Nomor 37 Tahun 2004 tentang Kepailitan dan Penundaan Kewajiban Pembayaran Utang. Kepailitan tidak lepas dengan bahasan Hukum Jaminan, termasuk sifat-sifat kreditornya yang pada hakekatnya bersifat lebih unggul daripada kreditor yang tidak menyertakan jaminan dalam piutangnya. Kendati demikian, dalam sifat yang unggul ini, kreditor yang telah memiliki jaminan pelunasan utangnya ini diperbolehkan untuk menjadi pemohon kepailitan pihak debitornya. Padahal melalui sifat unggulnya, penyelesaian piutang kreditor yang diunggulkan tersebut cukup komprehensif dan cepat caranya tanpa harus memohonkan pailit debitor.
\end{abstract}

Kata Kunci: kreditor, kepailitan, separatis.

\begin{abstract}
Bankruptcy is one way out that can be reached by the parties that were bound by credit agreement. Through the existence of bankruptcy rule, then it adds dispute solution in credit agreement, which was formerly be done simply by lawsuit of tort. Bankruptcy as a form of dispute resolution that has its own characteristics is the form of development from time to time, as the beginning rule is Article 750-910 Wetboek van Koophandel, until now the regulated through Act No. 37 of 2004 about Bankruptcy and Suspension of Debt Payment. Bankruptcy legal discussion is very related to the Security Law, including the character of its creditors who are in fact superior to creditors that do not include a security in their credit. However, the creditor who is superior and secured with security, is allowed to become an applicant party to the debtor Bankruptcy. Whereas through the excellence of their characteristic, the settlement if the debt is not paid is pretty fast and comprehensively ruled, without having to ask for the debtor Bankruptcy.
\end{abstract}

Keywords: creditors, bankruptcy, separatists.

\section{PENDAHULUAN}

Perkembangan dalam bidang bisnis, semakin menuntut para pelaku usaha untuk terus bersaing dalam mengembangkan bisnisnya, bisnis yang tidak dikembangkan, sudah barang tentu perlahan akan terhenti kegiatannya. Kemajuan dan kecanggihan teknologi juga tidak luput berperan serta dalam menunjang perkembangan bisnis, mempermudah masuk dan keluarnya barang dan jasa dari dalam ke luar negeri, atau sesama dalam negeri, begitu pula sebaliknya. Keadaan yang sangat menunjang berbagai macam bisnis yang dapat dilakukan oleh manusia untuk kelangsungan hidupnya, seperti jual beli atau perdagangan ini sungguh sangat bergantung pada perkembangan ekonomi.

Menyongsong kehidupan di dunia modern ini, perkembangan dalam bidang ekonomi itu sungguh merupakan suatu hal yang penting. Perkembangan sektor ekonomi menjadi tumpuan utama agar taraf hidup bangsa dapat lebih mapan, tingkat pertumbuhan ekonomi kini kian dicermati terus menerus oleh 
penguasa untuk dipacu agar mencapai angka yang diinginkan dan direncanakan. Tak urung dunia usaha sebagai tumpuan utama yang dijadikan alasan dan dipersiapkan berbagai langkah yang sekiranya dapat memupuk perkembangan ekonomi menjadi lebih optimal, terutama pembangunan dalam bidang perekonomian yang erat kaitannya dengan bidang permodalan yang sangat dibutuhkan dan juga dapat dianggap sebagai penunjang tercapainya perkembangan usaha tersebut. ${ }^{1}$

Aspek permodalan sebagai bagian dari perkembangan bidang perekonomian, merupakan aspek yang melibatkan bidang hukum, hal ini karena dalam hal permodalan, suatu pihak tentunya membutuhkan pihak lain yang bersedia menyediakan modal untuknya, di mana hal seperti ini dinamakan kegiatan perkreditan. Modal yang dibutuhkan kerapkali bukanlah suatu modal yang jumlahnya kecil. Modal yang dibutuhkan adalah modal yang besar, dengan persepsi bahwa modal tersebut akan digunakan untuk mencukupi biaya industri, perdagangan, produksi. Melalui pemberian modal yang cukup besar tersebut, sudah barang tentu para pihak yang terlibat di dalamnya membutuhkan kepastian dalam kedudukan dan perlindungan hukumnya. Hukum memberikan fasilitas perlindungan yang dicari oleh para pihak dalam perkreditan, yaitu melalui pranata yang disebut Hukum Jaminan. Hukum Jaminan berawal dari pengaturan dalam Burgerlijk Wetboek (yang selanjutnya disebut BW), prinsip dasar dari Hukum Jaminan ini adalah para pihak diberikan arahan untuk mendampingi kegiatan perkreditannya dengan penyertaan suatu jaminan demi keamanan dan kepastian pelunasan pemberian kredit tersebut.

Melalui Hukum Jaminan timbul 2 (dua) pihak, pertama yaitu pihak yang memberikan utang (berpiutang) dan diberi nama kreditor, kedua yaitu pihak yang diberikan utang (berutang) dan diberi nama debitor. Hukum Jaminan memberikan fasilitas berupa aturan-aturan, juga beberapa lembaga jaminan yang dapat digunakan oleh para pihak dalam perkreditan

\footnotetext{
${ }^{1}$ Oleh karena bertambah meningkatnya pembangunan nasional yang bertitik berat pada bidang ekonomi yang membutuhkan dana yang cukup besar, maka perlu adanya lembaga jaminan yang kuat dan mampu memberi kepastian hukum bagi pihak-pihak yang berkepentingan yang dapat mendorong peningkatan partisipasi masyarakat dalam pembangunan untuk mewujudkan masyarakat yang sejahtera, adil, makmur dan berdasarkan pancasila dan Undang-Undang Dasar 1945. Lihat Konsideran Rancangan Undang-Undang Republik Indonesia No. 4 Tahun 1996 tentang Hak Tanggungan.
}

sesuai sifat objek jaminannya. Jaminan merupakan sesuatu yang memiliki nilai dan diikat dalam suatu perikatan utang-piutang guna kepastian pelunasan perikatan tersebut. Objek jaminan dapat terdiri dari 2 (dua) macam, yaitu orang dan benda. Manakala objek jaminan itu berupa orang, maka pengaturannya tunduk pada Jaminan Perorangan. Kemudian saat objek jaminan itu berupa benda, maka pengaturannya tunduk pada Jaminan Kebendaan. Sebaliknya, apabila tidak diikat suatu jaminan dalam perikatan utangpiutang, hukum juga memberikan perlindungan bagi kreditor nya, yaitu melalui pengaturan Jaminan Umum.

Benda sebagai objek jaminan, sangat bervariasi penggolongannya, terdapat beberapa pembagian benda berdasarkan hukum Indonesia, antara lain: Benda berwujud dan tidak berwujud pada Pasal 503 BW; Benda bergerak dan tidak bergerak pada Pasal 504 BW; Benda habis pakai dan tidak habis pakai pada Pasal 505, 1754 BW; Benda sudah ada dan masih akan ada (Pasal 1131-1334 BW); Benda di dalam dan di luar perdagangan (Pasal $1332 \mathrm{BW}$ ); Benda dapat dibagi dan tidak dapat dibagi (Pasal 1163, 1296 BW); Benda dapat diganti dan tidak dapat diganti (Pasal 1694, 1750, 1754 BW); Benda ada pemiliknya dan tidak ada pemiliknya atau res nullius (Pasal 519 BW).

Di samping ke-8 (delapan) penggolongan tersebut, dalam perkembangannya, terdapat urgensi baru penggolongan benda yang terstruktur menjadi benda terdaftar dan benda tidak terdaftar. Karena merupakan suatu perkembangan, maka tidak ada aturannya di Indonesia mengenai benda terdaftar dan tidak terdaftar. Kendati demikian, penggolongan benda terdaftar dan tidak ini sangat berpengaruh dalam eksistensi hukum benda saat ini. Hal ini dikarenakan konsep benda terdaftar adalah benda yang ada dokumen hukumnya, dan memerlukan pendaftaran guna status hukum benda tersebut, sebaliknya untuk benda tidak terdaftar tidak memerlukan proses pendaftaran dalam hal penguatan status hukumnya.

Berdasarkan ke semua penggolongan benda tersebut di atas, penggolongan terpenting adalah benda bergerak dan benda tidak bergerak, hal ini selain karena semua pembagian benda tersebut di atas pada intinya adalah benda bergerak dan tidak bergerak, kemudian juga dalam pembagian benda bergerak dan tidak bergerak itu mewakili 5 (lima) aspek penting, yaitu: Bezit atau kedudukan 
berkuasa; Bezwaring atau penjaminan; Verjaring atau daluwarsa; Beslag atau penyitaan; Levering atau penyerahan. Perihal penjaminan, tunduk pada aspek Bezwaring, di mana melalui aspek tersebut muncul beragam aturan khususnya mengenai lembaga jaminan, yaitu untuk benda bergerak diberikan lembaga jaminan Gadai (Pasal 1150 hingga $1160 \mathrm{BW}$ ), sedangkan untuk benda tidak bergerak, diberikan lembaga jaminan yaitu Hipotek (Pasal 1162 hingga 1232 BW). Perkembangan ekonomi semakin menuntut perkembangan hukum, yang tidak terlepas juga pranata Hukum Jaminan, oleh karenanya lahir 2 (dua) lembaga jaminan baru selain Gadai dan Hipotek, yaitu lembaga jaminan Fidusia yang dikhususkan untuk benda bergerak modal (diatur melalui Undang-Undang No. 42 Tahun 1999 tentang Jaminan Fidusia), dan lembaga jaminan Hak Tanggungan yang dikhususkan untuk Hak Atas Tanah (diatur melalui Undang-Undang No. 4 Tahun 1996).

Kreditor yang memanfaatkan fasilitas dari Hukum Jaminan, mendapatkan keunggulan-keunggulan yang membuat kedudukannya menjadi lebih unggul daripada kreditor yang tidak memanfaatkan fasilitas dari Hukum Jaminan dalam perjanjian utangpiutangnya. Hal ini menandakan bahwa terdapat lebih dari satu macam kreditor. Melalui Hukum Jaminan, dikenal beberapa istilah kreditor yaitu: 1. Kreditor Konkuren tidak menyertakan jaminan dalam perjanjian kreditnya; 2. Kreditor Preferen menyertakan jaminan dalam perjanjian kreditnya; 3. Kreditor Privilege pemegang hak istimewa, berdasarkan sifat piutangnya. Ketiga kreditor tersebut memiliki peringkat dalam pelunasan piutang yang terjadi secara bersamaan.

Pelunasan piutang yang terjadi secara bersamaan, dapat terjadi karena utang yang jatuh tempo dalam waktu yang sama, atau karena pelunasannya dipaksa atas adanya suatu sengketa. Berkenaan dengan pelunasan suatu utang ini maka dapat dipahami bahwa hal itu bisa dilakukan karena 2 (dua) hal, karena pembayaran sesuai perjanjian, dan juga karena dipaksa oleh hukum untuk membayar utangnya (adanya sengketa). Sengketa yang dimaksud adalah pengajuan tuntutan kepada debitor ke Pengadilan, yang pada intinya hanya untuk utang debitor dilunasi. Melalui pengaturan Hukum Perdata, pengajuan tuntutan ke Pengadilan untuk pelunasan suatu utang adalah melalui gugatan wanprestasi. Seiring berkembangnya jaman, pengajuan tuntutan ke Pengadilan ini dapat dilakukan tidak hanya melalui gugatan wanprestasi, melainkan dapat berupa permohonan kepailitan.

Pada konsepnya kepailitan adalah sita umum atas semua harta kreditor, hal ini sebagaimana aturan Kepailitan yang tertuang dalam Undang-Undang No. 37 Tahun 2004 tentang Kepailitan dan Penundaan Kewajiban Pembayaran Utang (selanjutnya disebut UU KPKPU). Melalui konsep tersebut, maka jelas bahwa Hukum Kepailitan adalah bagian dari Hukum Jaminan. Hal ini dengan memahami redaksi Pasal 1131 BW yang bermakna sama dengan konsep kepailitan dalam UU KPKPU. Kendati demikian, melalui UU KPKPU juga diatur mengenai macammacam kreditor, yang sangat berbeda dengan macam-macam kreditor dalam Hukum Jaminan. Kreditor dalam UU KPKPU antara lain: (1). Kreditor Preferen (kreditor yang memiliki hak istimewa); (2). Kreditor Konkuren (kreditor yang tidak memiliki jaminan apapun dari debitor); (3). Kreditor Separatis (kreditor yang memiliki objek jaminan atas pelunasan perjanjian utang-piutangnya). Sehingga dapat diambil pengertian bahwa dalam Kreditor Preferen dalam Hukum Jaminan, adalah Kreditor Separatis dalam Hukum Kepailitan.

Hukum Kepailitan menjadi suatu metode penyelesaian sengketa utang-piutang yang banyak diminati oleh para pelaku usaha. Hal ini karena apabila dibandingkan dengan penyelesaian sengketa melalui gugatan wanprestasi, penyelesaian melalui kepailitan memakan waktu yang jauh lebih singkat, Pasal 8 ayat (4) UU KPKPU menegaskan bahwa Kepailitan harus telah diputus 60 (enam puluh) hari sejak permohonan diajukan. Syarat untuk memohon pailit pun cukup mudah, yaitu hanya dengan keberadaan utang, dan adanya minimal 2 (dua) kreditor, juga salah satu kreditor telah jatuh tempo, hal ini ditegaskan melalui Pasal 2 ayat (1) UU KPKPU. Pasal ini masih menimbulkan multitafsir mengenai apakah minimal dua kreditor itu semua harus mengajukan permohonan ke Pengadilan Niaga, atau cukup satu kreditor saja. Kemudian apabila salah satu kreditor tidak mau untuk debitor dipailitkan, maka yang seharusnya menjadi pertimbangan Hakim dalam hal ini, justru tidak dirumuskan dalam UU KPKPU.

Terlepas dari potensi multitafsir tersebut di atas, terdapat suatu kejelasan dalam Pasal 2 ayat (1) UU KPKPU tersebut di atas, bahwa Pasal tersebut menyebutkan kreditor, sehingga maksudnya adalah 
kreditor sebagai pemohon pailit debitor itu bisa merupakan Kreditor Preferen, Konkuren, dan Separatis (Penjelasan Pasal 2 ayat (1) UU KPKPU). Kreditor Separatis sebagaimana di atas sudah dituliskan, adalah Kreditor Preferen dalam Hukum Jaminan, yang mana memiliki objek jaminan yang dapat di eksekusi sewaktu-waktu guna pelunasan piutangnya. Sedangkan putusan pailit adalah mengikat semua kreditor, dan keadaan bisnis debitor akan terhenti saat putusan pailit itu dijatuhkan. Keadaan demikian kian terlihat janggal untuk suatu pengaturan yang tujuannya memberikan keadilan bagi semua kreditor dalam suatu proses utang-piutang.

Manakala Kreditor Separatis tidak menggunakan hak eksekusi objek jaminannya sebagai Kreditor Preferen dalam Hukum Jaminan, melainkan lebih memilih mempailitkan debitor, maka akibat kepailitan akan dirasakan juga oleh kreditor lainnya yang utangpiutangnya dengan debitor belum selesai. Hal ini karena setelah putusan pailit, keadaan bisnis debitor harus terhenti, dan segala harta kekayaannya menjadi boedel pailit yang diambil alih pengurusannya oleh curator. Mengingat putusan pailit dapat dijatuhkan dengan sangat cepat, sehingga pelunasan piutang kreditor dapat juga lebih cepat, hal ini jelas menarik minat kreditor, dan dalam waktu bersamaan juga menimbulkan ketakutan bagi kreditor yang utangpiutangnya dengan debitor masih belum selesai dan masih berpotensi mendapatkan keuntungan. Maka dari itu Pasal 2 ayat (1) UU KPKPU yang redaksinya menegaskan bahwa Kreditor Separatis bisa mengajukan permohonan pailit ini haruslah diadakan pembahasan lebih lanjut.

Berdasakan penjabaran latar belakang di atas, maka permasalahan yang akan dikaji dalam jurnal ilmiah ini adalah Eksistensi Kreditor Separatis Sebagai Pemohon dalam Perkara Kepailitan.

\section{PEMBAHASAN}

\section{Eksistensi Hukum Kepailitan dalam Konstelasi Hukum Indonesia}

Kepailitan merupakan suatu jalan keluar yang bersifat komersial untuk keluar dari persoalan utangpiutang yang menghimpit seorang debitor, di mana debitor tersebut sudah tidak mempunyai kemampuan lagi untuk membayar utang-utang tersebut pada kreditornya. ${ }^{2}$ Hukum Kepailitan merupakan suatu hukum di Indonesia yang terus berkembang, perkembangan terakhir yaitu sebagaimana diatur melalui UU KPKPU. Permulaan aturan tentang kepailitan, dan perkembangannya saat ini, dapat dirumuskan sebagai berikut:

Pertama, Hukum Kepailitan Sebelum Tahun 1945.

Peraturan kepailitan di masa ini merupakan bagian dari Wetboek van Koophandel (yang selanjutnya disebut $\mathrm{WvK}$ ) yang termuat dalam Buku III dengan judul Van de Voorzieningen in Geval van Onvermogen van Kooplieden (Peraturan tentang Ketidakmampuan Pedagang), khususnya dalam Pasal 749 hingga Pasal $910 \mathrm{WvK}$. Selain itu juga diatur dalam Reglement op de Rechtvordering (selanjutnya disingkat RV) khususnya dalam Bab Ketujuh Pasal 899 hingga Pasal 915 Rv mengenai Van Den Staat Van Kennelijk Onvermogen (tentang Keadaan Nyata-Nyata Tidak Mampu Yang Bukan Pedagang). Kedua pengaturan ini telah dicabut dengan Staatsblad 1906 No. 348.

Pada tahun 1905 diundangkan Verordening op bet Faillissement en Surceance van Betaling voor de European in Indonesia yang termuat dalam Staatsblads 1905 No. 217 jo. Staatsblads 1906 No. 348 (Faillissementrechts Verordering), yang mana berarti Peraturan Kepailitan dan Penundaan Pembayaran Untuk Golongan Eropa di Hindia Belanda. Peraturan ini mulai berlaku sejak tanggal 1 November 1906. Pada dasarnya aturan ini hanya berlaku bagi golongan Eropa. ${ }^{3}$ Faillissementrechts Verordering (selanjutnya disebut FV), dengan syaratsyarat tertentu dapat berlaku bagi golongan Bumi Putera (berdasarkan Staatsblads. 1917 No. 12), dan juga dapat berlaku bagi golongan Timur Asing Tionghoa (berdasarkan Staatsblads 1924 No. 556). Pasal 2 FV menyatakan tegas bahwa aturan yang ada dalam WvK dan RV mengenai kepailitan itu tidak lagi berlaku.

\section{Kedua, Hukum Kepailitan Pada Tahun 1945 Sampai} 1998.

${ }^{2}$ Hadi Subhan, Hukum Kepailitan, Prinsip, Norma dan Praktik di Pengadilan, Kencana Prenada Media, Jakarta, 2012, h. 2.

${ }^{3} \mathrm{Hal}$ ini mengingat saat itu masih adanya penggolongan penduduk berdasarkan Pasal 131 dan 163 IS. Penduduk di Indonesia (Hindia Belanda) dibagi ke dalam 3 (tiga) kelompok, Bumi Putera, Eropa, dan Timur Asing. Golongan Timur Asing juga dibagi lagi menjadi Timur Asing Tionghoa dan Timur AsingNon Tionghoa. 
Setelah kemerdekaan Indonesia, berdasarkan Pasal II Aturan Peralihan Undang-Undang Dasar 1945, FV dinyatakan tetap berlaku. Perubahan hanya terletak pada daya berlaku peraturan ini, yaitu untuk golongan Eropa, dan juga berlaku bagi golongan Bumi Putera dan Timur Asing tanpa syarat tertentu. Pada masa ini dibuat Peraturan Darurat Kepailitan yang mana bertujuan untuk memberikan dasar hukum bagi putusan pailit yang ada sebelum jatuhnya penjajahan Jepang. Setelah keberlakuan Peraturan Darurat Kepailitan itu usai, maka peraturan kepailitan kembali lagi mengacu pada FV.

Ketiga, Hukum Kepailitan Pada Tahun 1998 Sampai 2004. Pada tahun 1998 terjadi peristiwa yang cukup membawa perubahan besar pada peraturan kepailitan, yaitu adanya krisis moneter yang melanda Indonesia yang berdampak begitu banyak utang yang tidak dapat dilunasi. Pada masa ini Pemerintah Indonesia mengeluarkan Peraturan Pemerintah Pengganti Undang-Undang Nomor 1 Tahun 1998 tentang Perubahan atas Undang-Undang tentang Kepailitan (selanjutnya disebut PERPU Kepailitan 1998), pada tanggal 20 April 1998. Maksudnya Perubahan atas Undang-Undang tentang Kepailitan ini adalah bukan mengganti keseluruhan FV, melainkan hanya mengubah dan menambah FV. Melalui PERPU Kepailitan 1998 ini terdapat perubahan terhadap FV, antara lain: Mencabut 7 (tujuh) Pasal, yaitu Pasal 14a, 18, 218, 219, 221, 271), dan 1 (satu) ayat, yaitu Pasal 149 ayat (3); Merubah sebanyak 93 Pasal; Menambah 10 Pasal.

Melalui perubahan tersebut, maka Pasal di dalam FV jo. PERPU Kepailitan 1998 menjadi keseluruhan 282 Pasal. Pada tanggal 9 September 1998, melalui Dewan Perwakilan Rakyat Republik Indonesia (DPR RI), PERPU Kepailitan 1998 tersebut ditetapkan sebagai Undang-Undang, yang mana kemudian muncul Undang-Undang No. 4 Tahun 1998 tentang Penetapan Peraturan Pemerintah Pengganti UndangUndang No. 1 Tahun 1998 tentang Perubahan atas Undang-Undang tentang Kepailitan, menjadi UndangUndang (selanjutnya disebut UU Kepailitan Lama).

Dapat dipahami berarti peraturan kepailitan yang berlaku pada saat itu adalah UU Kepailitan Lama dan FV.

Keempat, Hukum Kepailitan Pada Tahun 2004 Sampai Sekarang. Setelah UU Kepailitan Lama itu berumur kurang lebih 6 (enam) tahun, ditetapkanlah Undang-Undang No. 37 Tahun 2004 tentang
Kepailitan dan Penundaan Kewajiban Pembayaran Utang, yang mulai berlaku sejak 18 Oktober 2004. Sejak saat itu hingga saat ini, peraturan kepailitan yang berlaku adalah UU KPKPU. UU KPKPU dikeluarkan atas beberapa pertimbangan, sebagaimana tertuang di dalam Konsideran dan Penjelasan Umumnya, antara lain: pertama, Bahwa dengan makin pesatnya perkembangan perekonomian dan perdagangan, makn banyak permasalaham utang piutang yang timbul dalam masyarakat; kedua, Bahwa krisis moneter yang terjadi di Indonesia telah memberikan dampak yang tidak menguntungkan terhadap perekonomian Nasional, sehingga menimbulkan kesulitan besar terhadap dunia usaha dalam menyelesaikan utang piutang untuk meneruskan kegiatannya; ketiga, Bahwa FV jo. UU Kepailitan Lama tidak sesuai lagi dengan perkembangan hukum di masyarakat.

UU KPKPU terdiri dari 308 Pasal, berdasarkan Ketentuan Peralihan dan Ketentuan Penutup UU KPKPU, maka: pertama, Semua peraturan perundangundangan yang merupakan peraturan pelaksanaan dari Fv jo. UU No. 4 Tahun 1998 masih tetap berlaku sejauh tidak bertentangan dan/atau belum diganti dengan peraturan baru berdasarkan UU KPKPU; kedua, FV jo. UU Kepailitan Lama dinyatakan tidak lagi berlaku aturan-aturannya, kecuali aturan pelaksanaannya yang tidak bertentangan dengan UU KPKPU; ketiga, Pengadilan Niaga pada Pengadilan Negeri Jakarta Pusat yang dibentuk berdasarkan Pasal 281 UU Kepailitan Lama dinyatakan tetap berwenang memeriksa dan memutus perkara yang menjadi lingkup tugas Pengadilan Niaga. ${ }^{4}$

Perkembangan sebagaimana dijabarkan di atas, menandakan bahwa kian eksis Hukum Kepailitan ini dalam konstelasi hukum di Indonesia. Kendati demikian, tidak menutup kemungkinan akan adanya permasalahan suatu saat nanti terkait kepailitan, walau aturannya terus berkembang. Oleh karena itu perlu diketahui lebih dalam, di mana letak Hukum Kepailitan ini apabila disejajarkan dengan pengaturan lain yang nuansanya juga bisnis. Hal ini karena melalui seluruh Pasal dalam UU KPKPU kian memberikan arahan bahwa ciri-ciri Hukum Kepailitan adalah dihadirkan dalam rangka kepentingan bisnis.

\footnotetext{
${ }^{4}$ Hal ini karena keberadaan Pengadilan Niaga pada Pengadilan Negeri Medan, Semarang, Surabaya dan Makassar yang dibentuk berdasarkan FV jo. UU Kepailitan Lama jo. Keputusan Presiden No. 97 Tahun 1999 ini tidak ada pengaturannya secara tegas, oleh karena itu keberlakuannya merujuk pada Pasal 305 UU KPKPU.
} 
Pasal 1 UU KPKPU menegaskan bahwa Kepailitan adalah sita umum atas semua kekayaan Debitor Pailit yang pengurusan dan pemberesannya dilakukan oleh Kurator di bawah pengawasan Hakim Pengawas. Kepailitan menurut Ivida adalah suatu proses di mana seorang debitor yang mempunyai kesulitan keuangan untuk membayar utangnya dinyatakan pailit oleh Pengadilan, dalam hal ini Pengadilan Niaga, dikarenakan debitor tersebut tidak dapat membayar utangnya. ${ }^{5}$ Sedangkan menurut Sularto, kepailitan diartikan sebagai suatu usaha bersama untuk mendapatkan pembayaran bagi semua kreditor secara adil dan tertib agar semua kreditor mendapat pembayaran menurut besar-kecilnya piutang masing-masing dengan tidak berebutan. ${ }^{6}$

Kedua pendapat di atas sama-sama mengartikan bahwa kepailitan ini selalau didasari dengan kesulitan keuangan dan utang yang tak terbayarkan. Menurut Nindya Pramono, hal ini dinamakan Emergency Window, sebagaimana diungkapkan olehnya sebagai berikut:?

Filosofi pailit merupakan emergency window, debitor keluar dari arena bisnis, baik karena terpaksa maupun dipaksa, karena salah satu hutang jatuh tempo dan dapat ditagih dan ada lebih dari satu kreditor, jadi pembuktiannya sangat sederhana. Dalam hal ini kepailitan berfungsi sebagai pintu keluar darurat, dengan demikian kepailitan ini sebisa mungkin diambil sebagai jalan terakhir ketika situasi lain sudah tidak memungkinkan. Rasio legis dari pemberlakuan putusan pailit secara serta merta adalah bahwa kepailitan pada dasarnya sebagai alat untuk mempercepat likuidasi terhadap harta-harta debitor untuk digunakan sebagai pembayaran utangutangnya.

Mendasar pada tiga pendapat tersebut di atas, juga Pasal 1 UU KPKPU, maka dapat diambil 7 (tujuh) unsur dari kepailitan, yaitu: Permasalahan keuangan; Adanya utang; Sita umum harta kekayaan debitor; Jalan keluar bagi kreditor; Ketertiban pelunasan utang

\footnotetext{
${ }^{5}$ Ivida Dewi Amrih Suci, Hak Kreditor Separatis dalam Mengeksekusi Benda Jaminan Milik Debitor Pailit, Laksbang Pressindo, Yogyakarta, 2011, h. 63.

${ }^{6}$ Sularto, "Perlindungan Hukum Kreditor Separatis Dalam Kepailitan”, Jurnal Mimbar Hukum Volume 24 No. 2, 2012, Universitas Gajah Mada, Yogyakarta, h. 247.

7 Keterangan Nindya Pramono sebagai Ahli dalam Persidangan Perkara Kepailitan No.02/Pdt.Sus PAILIT/2014/ PN NIAGA MKS, di Pengadilan Niaga Makassar.
}

debitor; Keadilan bagi para kreditor; Ada kurator dan Hakim Pengawas.

Beberapa di antara unsur-unsur sebagaimana disebutkan di atas, terdapat istilah kreditor, debitor, utang, dan sita umum harta kekayaan debitor. Demikian berarti atas adanya utang, muncul pihak kreditor dan debitor, dan demi pembayaran pelunasan utang tersebut maka proses sita umum harta kekayaan debitor itu diperlukan. Kegiatan sebagaimana dirangkai di atas ini mengarahkan pada suatu hukum yang mendasar, yang bernuansakan bisnis, tentang utang-piutang dan tentang pemaksaan pembayarannya, aturan hukum yang dimaksud adalah Hukum Jaminan yang diatur dalam BW.

Mendasarkan pada BW, pada prinsipnya tidak ada utang tanpa adanya agunan (jaminan), hal ini sebagaimana redaksi Pasal 1131 BW yang menegaskan bahwa segala kebendaan baik yang bergerak, tidak bergerak, sudah ada, dan masih akan ada, dijadikan jaminan bagi pelunasan suatu perikatan seseorang. Artinya, walaupun seseorang tidak menjaminkan suatu hal apapun dalam perjanjian utang-piutangnya, hukum senantiasa akan tetap melindungi pihak kreditor apabila pihak debitor cidera janji, dengan cara semua barang milik debitor dilakukan penyitaan dan penjualan untuk melunasi utangnya, hal ini dinamakan jaminan umum. Kendati demikian, hanya dengan memanfaatkan jaminan umum, kedudukan kreditor tetap sangat beresiko, karena dalam jaminan umum terkandung prinsip Paritas Creditorium.

Prinsip Paritas Creditorium merupakan dasar utama yang dapat digunakan untuk segala bentuk penyelesaian utang dari debitor terhadap para kreditornya, sebagaimana diungkapkan oleh Vollmar sebagai berikut: ${ }^{8}$ Een der belangrijkste beginselen van nederlands burgerlijk recht is neergelegd in de bapeling, dat de verhaalsrechten van den schuldeiser zich uitstrekken over alle roerende en onroerende goederen van den schuldenaar, zowel die hij heeft als die hij zal krijgen, atau Salah satu prinsip hukum terpenting adalah pelunasan utang dilakukan dengan memberikan hak kepada kreditor atas semua properti yang bergerak dan tidak bergerak milik debitor, dan terbagi secara seimbang dan terstruktur berdasarkan peringkat-peringkat kreditornya. (terjemahan bebas penulis)

${ }^{8}$ Vollmar, De Faillessementswet, Tjenk Willink \& Zoon N.V., Harlem, 1948, h. 1. 
Prinsip Paritas Creditorium merupakan prinsip yang menegaskan bahwa utang, baik itu baru ataupun lama, jumlahnya besar ataupun kecil, semua kedudukannya sama rata. Prinsip ini adalah yang menjadi dasar aturan Pasal 1132 BW yang menegaskan: Kebendaan tersebut menjadi jaminan bersama-sama bagi semua orang yang mengutangkan kepadanya; pendapatan penjualan benda-benda itu dibagi-bagi menurut keseimbangan, yaitu menurut besar-kecilnya piutang masing-masing, kecuali apabila di antara para berpiutang itu ada alasan-alasan yang sah untuk didahulukan.

Pasal 1132 BW tersebut, selain termuat prinsip Paritas Creditorium, juga memuat prinsip Pari Pasu Prorata Parte, yang artinya adalah pembayaran utang-utang tersebut dibagi-bagi kepada kreditorkreditornya berdasarkan keseimbangan, yaitu menurut besar-kecilnya piutang masing-masing. Melalui penjabaran di atas, Pasal 1131 BW, dan prinsip Paritas Creditorium juga prinsip Pari Passu Prorata Parte dalam Pasal 1132 BW sebagai aturan lanjutan dari Pasal 1131 BW, diketahui bahwa sebenarnya kepailitan yang didefinisikan dalam Pasal 1 UU KPKPU itu merupakan pelaksanaan lebih lanjut dari aturan-aturan tersebut, dengan demikian kepailitan merupakan aturan lanjutan dan pengejewantahan dari Hukum Jaminan.

Kartini Muljadi berpendapat bahwa prinsip Paritas Creditorium dan prinsip Pari Passu Prorata Parte merupakan landasan dari aturan-aturan tentang kepailitan, dikatakan oleh Kartini Muljadi sebagai berikut: ${ }^{9}$ Kepailitan adalah merupakan pelaksanaan lebih lanjut dari prinsip Paritas Creditorium dan prinsip Pari Passu Prorate Parte dalam rezim hukum harta kekayaan atau vermogensrechts. Prinsip paritas creditorium berarti bahwa semua kekayaan debitor baik yang berupa barang bergerak atau pun barang tidak bergerak maupun harta yang sekarang telah dipunyai debitor dan barang-barang di kemudian hari akan dimiliki debitor terikat kepada penyelesaian kewajiban debitor. Sedangkan prinsip Pari Passu Prorata Parte berarti bahwa harta kekayaan tersebut merupakan jaminan bersama untuk para kreditor dan hasilnya harus dibagikan secara proporsional antara mereka, kecuali apabila antara para kreditor itu ada

\footnotetext{
${ }^{9}$ Kartini Muljadi, Kepailitan dan Penyelesaian UtangPiutang, dalam Rudhy A. Lontoh, Penyelesaian Utang-Piutang Melalui Pailit atau Penundaan Kewajiban Pembayaran Utang, Alumni, Bandung, 2001, h. 168. (selanjutnya disebut Kartini Muljadi 1)
}

yang menurut undang-undang harus didahulukan dalam menerima pembayaran tagihannya.

Diungkapkan juga oleh Kartini Muljadi dalam karya tulisnya yang lain, sebagai berikut: ${ }^{10}$ Rumusan Pasal 1131 BW, menunjukkan bahwa setiap tindakan yang dilakukan seseorang dalam lapangan harta kekayaan selalu akan membawa akibat terhadap harta kekayaannya, baik yang bersifat menambah jumlah harta kekayaannya atau kredit, maupun yang nantinya akan mengurangi jumlah harta kekayaannya atau debit. Pasal 1132 BW menentukan bahwa setiap pihak atau kreditor yang berhak atas pemenuhan perikatan, haruslah mendapatkan pemenuhan perikatan dari harta kekayaan pihak yang berkewajiban atau debitor tersebut secara Parri Passu dan Prorata atau proporsional, yang dihitung berdasarkan pada besarnya piutang masing-masing dibandingkan terhadap piutang mereka secara keseluruhan, terhadap seluruh harta kekayaan debitor tersebut.

Selanjutnya juga dikatakan oleh Kartono, bahwa pada prinsipnya, pengaturan masalah kepailitan merupakan suatu perwujudan atau pengejawantahan dari Pasal 1131 dan Pasal 1132 BW. Ditegaskan dalam Pasal tersebut bahwa segala kebendaan si berutang, baik yang bergerak maupun yang tak bergerak, baik yang sudah ada maupun yang baru akan ada di kemudian hari, menjadi tanggungan untuk segala perikatan perseorangan, dan kebendaan tersebut menjadi jaminan bersama-sama bagi semua orang yang mengutangkan padanya. ${ }^{11}$ Dijabarkan juga bahwa: ${ }^{12}$ pertama, Apabila si debitor tidak membayar utangnya dengan sukarela atau tidak membayarnya, walaupun telah ada keputusan pengadilan yang menghukumnya supaya melunasi utangnya, atau karena tidak mampu untuk membayar seluruh utangnya, maka semua harta bendanya disita untuk dijual, dan hasil penjualan itu dibagi-bagikan antara semua kreditornya secara Ponds Ponds Gewijze, artinya menurut perimbangan, yaitu menurut besar kecilnya piutang masing-masing kreditor, kecuali apabila di antara para kreditor itu ada alasan-alasan yang sah untuk didahulukan; kedua, Semua kreditor mempunyai hak yang sama; ketiga, Tidak ada nomor

${ }^{10}$ Kartini Muljadi, Prosiding Masalah-Masalah Kepailitan dari Wawasan Hukum Bisnis, Pusat Pengkajian Hukum, Jakarta, 2005, h. 164. (selanjutnya disebut Kartini Muljadi 2)

${ }^{11}$ Kartono, Kepailitan dan Pengunduran Pembayaran, Pradnya Paramita, Jakarta, 1974, h. 7.

${ }^{12}$ Ibid. 
urut dari para kreditor yang didasarkan atas saat timbulnya piutang-piutang mereka.

Jerry Hoff, menegaskan bahwa suatu hukum kepailitan dapat memenuhi tujuan-tujuan di bawah ini: ${ }^{13}$

Pertama, Meningkatkan upaya pengembalian kekayaan. Kekayaan debitur harus ditampung dalam suatu kumpulan dana yang sama-disebut harta kepailitan-yang disediakan untuk pembayaran tuntutan kreditor. Kepailitan menyediakan suatu forum untuk likuidasi secara kolektif atas aset debitur.

Kedua, Memberikan perlakuan baik yang seimbang dan yang dapat diperkirakan sebelumnya kepada para kreditor. Pada dasarnya, para kreditor dibayar secara pari passu; mereka menerima suatu pembagian secara pro rata parte dari kumpulan dana tersebut sesuai dengan besarnya tuntutan masingmasing. Prosedur dan peraturan dasar dalam hubungan ini harus dapat memberikan suatu kepastian dan keterbukaan. Kreditor harus mengetahui sebelumnya mengenai kedudukan hukumnya.

Ketiga, Memberikan kesempatan yang praktis untuk reorganisasi perusahaan yang sakit, tetapi masih potensial bila kepentingan para kreditor dan kebutuhan sosial dilayani dengan lebih baik dengan mempertahankan debitor dalam kegiatan usahanya.

Bertolak dari penjabaran di atas, dapat ditarik suatu pengertian, bahwa dengan adanya Kepailitan yang mana merupakan tindakan tegas berupa keputusan, yang berisi ketidakmampuan lagi seseorang untuk melakukan perbuatan hukum terkait harta kekayaannya, maka kepada seseorang tersebut semua hartanya (yang memenuhi unsur Pasal 1131 BW) yang bisa dipindahtangankan, akan disita, dan ada di bawah pengurusan Kurator dengan bantuan pengawasan dari Hakim Pengawas. Beberapa karakter kepailitan yang mana tidak adanya jumlah minimum utang, menghindarkan pertentangan apabila ada beberapa kreditor pada waktu yang sama meminta pembayaran piutangnya dari debitor, menghindari kecurangan debitor, dan bertujuan untuk meningkatkan upaya pengembalian kekayaan, memberikan perlakuan baik yang seimbang dan yang dapat diperkirakan sebelumnya kepada para kreditor, dan memberikan kesempatan yang praktis untuk reorganisasi perusahaan yang sakit, tetapi masih potensial, menunjukkan bahwa kepailitan ini hadir

13 Jerry Hoff, Undang-Undang Kepailitan Indonesia (Indonesian Bankrupcty), Tatanusa, Jakarta, 2000, h. 9-10. untuk kepentingan bisnis, baik itu untuk kepentingan bisnis debitor dan/atau kepentingan bisnis kreditor.

Berdasarkan aturan-aturan dan pendapat ahli sebagaimana dijabarkan di atas, maka dapat dipahami bahwa Hukum Kepailitan dihadirkan dalam rangka kepentingan bisnis, dan merupakan pelaksanaan dari Hukum Jaminan Pasal 1131 dan 1132 BW. Oleh karenanya, eksistensi Hukum Kepailitan merupakan salah satu tindakan lebih lanjut guna penegakan Hukum Jaminan, sehingga Hukum Jaminan merupakan rumah dari Hukum Kepailitan, dan tidak semestinya keduanya mempunyai prinsip yang bertentangan satu sama lainnya.

\section{Pemaknaan Kreditor dalam Hukum Jaminan dan Kepailitan}

Setelah diketahui bahwa Hukum Kepailitan merupakan bagian dari Hukum Jaminan, maka dapat dipahami bahwa keduanya sudah barang tentu mengenal dan memiliki pihak yang bernama kreditor, yaitu pihak yang berhak atas suatu prestasi dari debitor. Kendati keduanya (Hukum Jaminan dan Hukum Kepailitan) adalah satu bagian, namun dalam hal pemaknaan kreditor, keduanya memiliki perbedaan, artinya kreditor dalam Hukum Jaminan berbeda dengan Kreditor dalam Hukum Kepailitan. Perbedaan yang dimaksud bukan hanya perbedaan konsep atau istilah saja, melainkan dari pemaknaan dan sifat-sifat masing-masing kreditor yang ada dalam Hukum Jaminan mengalami pergeseran makna dalam aturan Hukum Kepailitan.

Pertama, Kreditor dalam Hukum Jaminan.

Pada dasarnya kedudukan para kreditor adalah sama atau paritas creditorium dan karenanya mempunyai hak yang sama atas hasil eksekusi sesuai dengan besarnya tagihan mereka masing-masing atau pari passu pro rata parte, namun demikian asas tersebut mengenal pengecualian yaitu golongan Kreditor yang memegang hak agunan atas kebendaan dan golongan Kreditor yang haknya didahulukan, sehingga asas Paritas Creditorium berlaku bagi para kreditor konkuren saja. ${ }^{14}$ Kreditor dari Hukum Jaminan, terdapat 3 (tiga) macam, yaitu Kreditor Konkuren; Kreditor Preferen; dan Kreditor Privilege.

${ }^{14}$ Fred B.G. Tumbuan, Pokok-Pokok Undang-Undang tentang Kepailitan sebagaimana diubah oleh Perpu Nomor. 1 Tahun 1998, dalam Penyelesaian Utang Piutang melalui Pailit atau Penundaan Kewajiban Pembayaran Utang, Editor: Rudhi A. Lontoh, Alumni, Bandung, 2001, h. 128. 
Kreditor konkuren lahir dari jaminan umum yang diatur dalam Pasal 1131 jo. 1132 BW. Kreditor konkuren adalah para kreditor dengan hak pari passu dan pro rata, artinya para kreditor secara bersama-sama memperoleh pelunasan (tanpa ada yang didahulukan), yang dihitung berdasarkan besarnya piutang masing-masing dibanding piutang mereka secara keseluruhan, dan seluruh harta kekayaan debitor. Dengan demikian, para kreditor konkuren mempunyai kedudukan yang sama atas utang yang baru, lama, besar atau pun kecil, juga pelunasan piutang dari harta debitor tanpa ada yang didahulukan. ${ }^{15}$

Kreditor Preferen lahir karena jaminan khusus (Pasal 1132 jo. 1133 BW) yang mempunyai hakhak jaminan khusus seperti hak yang memberikan kepada kreditor kedudukan yang lebih baik dibanding kreditor lain dalam pelunasan hutangnya karena diberikan oleh undang-undang atau diperjanjikan

Diungkapkan oleh Subekti, ${ }^{16}$ bahwa Jaminan khusus ini adalah antara kreditor dan debitor memiliki suatu jaminan untuk pelunasan utang yang lebih mudah dan terjamin, karena itu ada satu benda yang diikat secara khusus sebagai pelunasan hutang, maka dari itulah menjadi jaminan khusus. Karena suatu benda itu diikat untuk seorang atau lebih kreditor, maka kreditor itu akan didahulukan pelunasan hutangnya, yaitu adanya preferensi, hal ini adalah sifat jaminan khusus berupa Droit De Preference atau adanya preferensi. Maka dapat disimpulkan jaminan khusus terkandung sifat yaitu hak yang lahir adalah hak kebendaan, bersifat mutlak, ada droit de suite, ada preferensi, ada prioritas, ada gugat kebendaan, dan bersifat separatis.

Dasar pengaturan kreditor preferen adalah Pasal 1132 BW, yang mana redaksi kalimat terakhirnya menegaskan bahwa dimungkinkan adanya pendahuluan pelunasan utang, apabila terdapat alasan-alasan yang sah. Karena sifatnya didahulukan ini, maka terdapat preferensi dari Kreditor Konkuren yang diatur dalam Pasal 1131 BW, oleh karenanya kreditor ini dinamakan Kreditor Preferen.

Alasan yang sah yang dimaksud ini adalah adanya hal yang diikat secara khusus dalam perikatan perjanjian utang-piutang antara debitor dan kreditor

\footnotetext{
${ }^{15}$ Munir Fuady, Hukum Pailit dalam Teori dan Praktek, Citra Aditya Bakti, Bandung, 2002, h. 1.

16 R. Subekti, Suatu Tinjauan tentang Sistem Hukum Jaminan Nasional, Binacipta, Jakarta, 1981, h. 24.
}

guna kepastian pelunasan utang debitor kepada kreditor. Hal yang dimaksud ini adalah jaminan. Sehingga apabila ada jaminan yang diikat dalam perikatan utang-piutang kreditor dan debitor, maka kreditornya menjadi kreditor preferen dan memiliki kedudukan pelunasan utang yang didahulukan daripada kreditor yang tidak mengikat jaminan untuk perikatan utang-piutangnya.

Kreditor privilege adalah salah satu kreditor yang diistimewakan dan didahulukan pelunasan utangnya sebagaimana disebutkan dalam Pasal 1134 BW. Kreditor privilege ini mempunyai sifat didahulukan pelunasan piutangnya karena UndangUndang memberikannya, dan bukan karena perjanjian jaminan yang dibuat oleh para pihak sebagaimana kreditor preferen. Hak kreditor yang terjadi karena undang-undang ini disebutkan dengan istilah teknis Privilege. ${ }^{17}$

Meski mempunyai sifat yang mirip dengan hak kebendaan, namun bukanlah merupakan hak kebendaan, dan bukanlah hal yang tidak mungkin untuk adanya benturan dengan hak kebendaan atau hak lainnya. Kreditor privilege ini hanya mendapatkan preferensinya bila diminta. Diutarakan oleh Herlin Budiono bahwa Hak istimewa atau privilege adalah hak yang oleh undang-undang diberikan kepada seorang berpiutang sehingga tingkatannya lebih tinggi daripada orang berpiutang lainnya, untuk dari hasil eksekusi mendapatkan pembayaran yang didahulukan, semata-mata berdasarkan sifat piutangnya. ${ }^{18}$

Ditambahkan oleh Subekti dalam bukunya bahwa: ${ }^{19}$ Piutang-piutang semacam ini dinamakan bevoorrechte schulden. Meskipun privilege ini mempunyai sifat-sifat yang menyerupai panda tau hipotek, tetapi kita belum dapat menamakannya suatu hak kebendaan, karena privilege ini barulah timbul apabila suatu kekayaan yang telah disita ternyata tidak cukup untuk melunasi semua hutang dan arena privilege itu tidak memberikan suatu kekuasaan terhadap suatu benda. Seorang penagih yang mempunyai privilege pun tidak dapat menyita suatu

${ }^{17}$ Mariam Darus Badrulzaman, Mencari Sistem Hukum Benda Nasional, Alumni, Bandung, 2010, h. 86.

${ }^{18}$ Herlin Budiono, Kumpulan Tulisan Hukum Perdata di Bidang Kenotariatan, Citra Aditya Bakti, Bandung, 2008, h. 108.

19 Subekti, Pokok-Pokok Hukum Perdata, Intermasa, Bandung, 2003, h. 88. 
benda jika ia tidak mempunyai title eksekutorial, misalnya suatu putusan hakim.

Menurut Pasal 1138 BW, ada 2 (dua) macam privilege, yaitu Privilege Khusus (Pasal 1139 BW), dan Privilege Umum (Pasal 1149 BW), menurut Pasal 1139 BW, privilege khusus ada 9 (sembilan macam) yaitu piutang-piutang yang diistimewakan terhadap benda-benda tertentu adalah:

Pertama, Biaya perkara yang semata-mata disebabkan suatu penghukuman untuk melelang suatu benda bergerak maupun tidak bergerak. Biaya ini dibayar dari pendapatan penjualan benda tersebut terlebih dahulu dari semua piutang-piutang lainnya yang diistimewakan, bahkan lebih dulu dari Gadai dan Hipotek; Kedua, Uang-uang sewa dari bendabenda tak bergerak, biaya-biaya perbaikan yang menjadi wajibnya si penyewa, beserta segala apa yang mengenai kewajiban persetujuan sewa; Ketiga, Harga pembelian benda-benda bergerak yang belum dibayar; Keempat, Biaya yang telah dikeluarkan untuk menyelamatkan suatu barang; Kelima, Biaya untuk melakukan suatu pekerjaan pada suatu barang, yang masih harus dibayar kepada seorang tukang; Keenam, Apa yang telah diserahkan oleh seorang pengusaha rumah penginapan sebagai demikian kepada seorang tamu; Ketujuh, Upah-upah pengangkutan dan biayabiaya tambahan; Kedelapan, Apa yang harus dibayar kepada tukang-tukang batu, tukang-tukang kayu dan lain-lain tukang pembangunan, penambahan dan perbaikan-perbaikan benda tak bergerak, asal saja piutangnya tidak lebih tua dari tiga tahun dan hak milik atas persil yang bersangkutan masih tetap ada pada si berutang

Berdasarkan rumusan yang diberikan dalam Pasal 1139 BW ini dapat diketahui adanya 9 (sembilan) jenis piutang yang harus didahulukan pelunasan atau pembayaran atas penjualan kebendaan tertentu. Kedua adalah Privelege Umum (Pasal 1149 BW) yang juga menjabarkan adanya 7 (tujuh) macam privilege umum, yaitu piutang-piutang yang diistimewakan atas semua benda bergerak dan tak bergerak pada umumnya ialah yang disebutkan di bawah ini piutangpiutang mana dilunasi dari pendapatan penjualan benda-benda itu menurut urutan sebagai berikut: Biaya perkara; Biaya penguburan; Biaya pengobatan terakhir dari seorang debitor yang meninggal dunia (biaya ini meliputi biaya dokter, pembelian obat dan perawatan rumah sakit); Tagihan buruh atas upahnya untuk satu tahun dalam tahun kerja yang sedang berjalan; Uang pembelian barang-barang makanan untuk hidup sehari-hari yang diperlukan oleh si berutang dan keluarganya; Tagihan sekolah asrama untuk satu tahun terakhir; Piutang seorang yang belum dewasa atau seorang yang berada di bawah pengampuan terhadap seorang wali atau kurator.

Perbedaannya, privilege dalam Pasal 1139 BW, tidak menentukan urutannya, namun dalam Pasal 1149 BW ditentukan urutannya, yang lebih dahulu disebut itu yang didahulukan pembayarannya. ${ }^{20}$ Privilege umum lebih mempunyai arti akan hak tagihan yang diistimewakan dalam mengambil perlunasan atas hasil penjualan dalam suatu eksekusi atas semua benda milik debitor, sedangkan privilege khusus adalah piutang-piutang yang diistimewakan terhadap benda-benda tertentu. ${ }^{21}$

Seperti halnya hak kebendaan, kreditor privilege ini mempunyai hak yang memberikan jaminan untuk didahulukan atau preference pembayarannya, meski mempunyai sifat yang mirip dengan hak kebendaan, namun bukanlah merupakan hak kebendaan, dan bukanlah hal yang tidak mungkin untuk adanya benturan dengan hak kebendaan atau hak lainnya. Kreditor privilege dan kreditor preferen sama-sama mendapatkan pelunasan yang didahulukan, namun pada umumnya kreditor preferen didahulukan pelunasannya daripada kreditor privilege, kecuali ditentukan lain oleh Undang-Undang. Hal ini sebagaimana diungkapkan oleh Mariam Darus Badrulzaman, yaitu: Dilihat dari tingkat atau rangorde hak yang didahulukan, maka kreditor preferen (Gadai dan Hipotek) mendapat tingkat tertinggi dan sesudah itu menyusul privilege, ini adalah asas umum. Terhadap asas umum ini UndangUndang mengadakan pengecualian yaitu dalam hal Undang-Undang menentukan lain, berdasarkan sifat sesuatu piutangnya (Pasal 1134 BW). Untuk mengetahui sifat-sifat piutang yang diurut menurut prioritasnya dalam privelege khusus dan umum dapat dilihat Pasal 1139 dan 1149 BW. Jika secara umum hendak menyusun urutan hak yang didahulukan ini, maka akan terlihat sebagai berikut: 1. Pasal 1139 angka $1 \mathrm{BW}$, yaitu biaya perkara karena lelang benda tertentu atau Privilege Khusus; 2. Pasal 1149 angka 1 BW, yaitu biaya perkara yang disebabkan lelang dan penyelesaian suatu warisan atau Privilege Umum; 3.

\footnotetext{
${ }^{20}$ Djaja S. Meliala, Perkembangan Hukum Perdata tentang benda dan Hukum Perikatan, Nuansa Alia, Bandung, 2007, h. 24. 21 Ibid.
} 
Gadai, Hipotek, Hak Tanggungan dan Fidusia atau Kreditor Preferen; 4. Privilege selebihnya; 5. Kreditor Konkuren.

\section{Kedua, Kreditor dalam Hukum Kepailitan}

Berdasarkan Pasal 1 angka (2) UU KPKPU, kreditor adalah orang yang mempunyai piutang karena perjanjian atau undang-undang yang dapat ditagih di muka Pengadilan. Penjelasan Pasal 2 ayat (1) UU KPKPU menegaskan bahwa yang dimaksud dengan Kreditor dalam UU KPKPU adalah Kreditor Konkuren, Kreditor Separatis, dan Kreditor Preferen. Kreditor Separatis dan Kreditor Preferen dapat mengajukan permohonan Pailit tanpa kehilangan hak agunan atas kebendaan yang mereka miliki terhadap harta debitor, dan hak tersebut adalah didahulukan.

Mendasar pada Pasal dan Penjelasan Pasal di atas, maka dapat dipahami bahwa dalam Hukum Kepailitan terdapat 3 (tiga) jenis kreditor, dan diantaranya ada yang mempunyai hak untuk didahulukan, yaitu Kreditor Separatis (didahulukan), Kreditor Preferen (didahulukan), Kreditor Konkuren.

Pasal 60 ayat (1) UU KPKPU menegaskan bahwa: Kreditor pemegang hak sebagaimana Pasal 55 ayat (1) UU KPKPU wajib memberikan pertanggungjawaban kepada Kurator tentang hasil penjualan benda yang menjadi agunan dan menyerahkan sisa hasil penjualan setelah dikurangi jumlah utang, bunga, dan biaya kepada Kurator.

Pasal 60 ayat (2) UU KPKPU menegaskan bahwa: Atas tuntutan Kurator atau kreditor yang diistimewakan yang kedudukannya lebih tinggi daripada kreditor pemegang hak sebagaimana dimaksud pada ayat (1), maka kreditor pemegang hak tersebut wajib menyerahkan bagian dari hasil penjualan tersebut untuk jumlah yang sama dengan jumlah tagihan yang diistimewakan.

Mendasar pada kedua Pasal tersebut, maka kreditor yang disebutkan dalam Pasal 60 ayat (2) UU KPKPU kedudukannya lebih tinggi daripada yang disebutkan dalam Pasal 60 ayat (1) UU KPKPU.

Penjelasan Pasal 60 ayat (2) UU KPKPU menjelaskan bahwa Kreditor Yang Diistimewakan tersebut adalah sebagaimana dimaksud dalam Pasal 1139 dan 1149 BW. Pasal 1139 dan 1149 BW mengatur tentang Kreditor Privilege (Privilege Umum dan Privilege Khusus dalam Hukum Jaminan). Sedangkan maksud dari kreditor dalam Pasal 60 ayat (1) UU KPKPU adalah sebagaimana yang disebutkan dalam Pasal 55 ayat (1) UU KPKPU. Pasal 55 ayat (1) UU KPKPU menegaskan bahwa: Dengan tetap memperhatikan ketentuan sebagaimana dimaksud dalam Pasal 56, Pasal 57, dan Pasal 58 UU KPKPU, setiap kreditor pemegang Gadai, Jaminan Fidusia, Hak Tanggungan, Hipotek, atau hak agunan atas kebendaan lainnya, dapat mengeksekusi haknya seolah-olah tidak terjadi Kepailitan.

Berdasarkan pengaturan tersebut di atas, dapat diambil pengertian bahwa dalam Kepailitan itu Kreditor yang Diistimewakan lebih didahulukan daripada Kreditor Pemegang Jaminan Kebendaan. Apabila istilah kreditor tersebut di konfersi menajdi istilah dalam pengaturan Hukum Jaminan, maka berarti dalam Hukum Kepailitan, Kreditor Privilege mempunyai kedudukan yang lebih tinggi daripada Krediitor Preferen.

Mengenai Kreditor Konkuren, dalam Hukum Kepailitan diatur bahwa Kreditor Konkuren adalah kreditor yang tidak mempunyai hak untuk didahulukan, hal ini terdapat dalam redaksi Pasal 149 UU KPKPU, yang menegaskan: Pertama, Pemegang Gadai, Jaminan Fidusia, Hak Tanggungan, Hipotek, atau hak agunan atas kebendaan lainnya dan Kreditor yang diistimewakan, termasuk Kreditor yang mempunyai hak didahulukan yang dibantah, tidak boleh mengeluarkan suara berkenaan dengan rencana perdamaian, kecuali apabila mereka telah melepaskan hak nya untuk didahulukan, demi kepentingan harta pailit sebelum diadakannya pemungutan suara tentang rencana perdamaian tersebut. Kedua, Dengan pelepasan hak sebagaimana dimaksud pada ayat (1), mereka menjadi Kreditor Konkuren, juga dalam hal perdamaian tersebut tidak bisa diterima.

Redaksi pasal tersebut di atas, adalah apabila seorang kreditor yang didahulukan itu melepaskan haknya untuk didahulukan, maka kreditor tersebut menjadi Kreditor Konkuren. Secara a contrario, berarti Kreditor Konkuren adalah kreditor yang tidak mempunyai hak untuk didahulukan.

Sedasar dengan penjabaran di atas, maka dapat diambil suatu pengertian bahwa urutan-urutan kreditor (dan peringkatnya) dalam Hukum Kepailitan adalah: Kreditor yang diistimewakan; Kreditor yang memegang jaminan Gadai, Fidusia, Hak Tanggungan, dan Hipotek; Kreditor Konkuren.

Penjabaran sebelumnya telah dijabarkan bahwa kreditor dalam Kepailitan ada Kreditor Separatis (didahulukan), Kreditor Preferen (didahulukan), dan 
Kreditor Konkuren. Melalui urutan-urutan kreditor yang ditemukan di atas, maka kini perlu ditelusuri yang manakah Kreditor Preferen dan yang manakah Kreditor Separatis. Penentuan mana Kreditor Preferen dan mana Kreditor Separatis ini, perlu beranjak dari Pasal 55 ayat (1) dan Pasal 191 UU KPKPU. Pasal 55 ayat (1) UU KPKPU. Pasal 55 ayat (1) UU KPKPU menegaskan bahwa: Dengan tetap memperhatikan ketentuan sebagaimana dimaksud dalam Pasal 56, Pasal 57, dan Pasal 58 UU KPKPU, setiap kreditor pemegang Gadai, Jaminan Fidusia, Hak Tanggungan, Hipotek, atau hak agunan atas kebendaan lainnya, dapat mengeksekusi haknya seolah-olah tidak terjadi Kepailitan.

Pasal 191 UU KPKPU menegaskan bahwa: Semua biaya kepailitan dibebankan kepada setiap benda yang merupakan bagian harta pailit, kecuali benda yang menurut ketentuan sebagaimana dimaksud dalam Pasal 55 telah dijual sendiri oleh Kreditor pemegang Gadai, Jaminan Fidusia, Hak Tanggungan, Hipotek atau hak agunan atas kebendaan lainnya.

Mendasarkan pada kedua pengaturan Pasal di atas, maka dapat diketahui bahwa kreditor pemegang jaminan Gadai, Fidusia, Hak Tanggungan dan Hipotek, mendapatkan keistimewaan, yaitu dapat mengeksekusi haknya seolah-olah tidak terjadi Kepailitan, dan juga tidak dapat dibebani dengan biaya Kepailitan. Hal ini memberikan suatu pengertian bahwa kreditor pemegang jaminan kebendaan (Gadai, Hipotek, Hak Tanggungan dan Fidusia) sifatnya berbeda dengan kreditor lainnya, sifatnya terpisah dari kreditor lainnya. Terpisahnya sifat kreditor pemegang jaminan kebendaan ini, mengindikasikan bahwa katakata separatis dalam UU KPKPU tersebut ditujukan untuk kreditor pemegang jaminan kebendaan. Man. S. Sastrawidjaja menjabarkan bahwa: ${ }^{22}$ Kreditor Separatis adalah kreditor yang dapat melaksanakan haknya seolah-olah tidak terjadi Kepailitan, seperti pemegang Gadai, Jaminan Fidusia, Hak Tanggungan, Hipotek dan agunan lainnya.

Pendapat Man. S. Sastrawidjaja tersebut di atas, semakin menegaskan dan koheren bahwa yang dimaksud dengan Kreditor Separatis (dalam Hukum Kepailitan) adalah kreditor pemegang jaminan kebendaan (pemegang Gadai, Hipotek, Fidusia, dan Hak Tanggungan).

${ }^{22}$ Man. S. Sastrawidjaja, Hukum Kepailitan dan Penundaan Kewajiban Pembayaran Utang, Alumni, Bandung, 2006, h. 127.
Penelusuran tentang siapa itu Kreditor Separatis, membawa pengertian bahwa saat ini kreditor (dan peringkatnya) dalam Hukum Kepailitan adalah: Kreditor yang diistimewakan; Kreditor Separatis (kreditor yang memegang jaminan Gadai, Fidusia, Hak Tanggungan, dan Hipotek); Kreditor Konkuren.

Satu-satunya kreditor yang belum mendapatkan istilah adalah kreditor yang diistimewakan. Sedang istilah kreditor dalam Hukum Kepailitan ada satu yang belum tersebut, yaitu Kreditor Preferen. Oleh karenanya, berarti kreditor yang diistimewakan adalah yang dimaksud dengan Kreditor Preferen dalam Hukum Kepailitan. Hal ini sebagaimana kata preferen yang diambil dari kata preferensi yang artinya didahulukan atau diistimewakan. Sehingga berdasarkan penjabaran di atas kreditor (dan peringkatnya) dalam Hukum Kepailitan, adalah: Kreditor Preferen (kreditor yang diistimewakan); Kreditor Separatis (kreditor yang memegang jaminan Gadai, Fidusia, Hak Tanggungan, dan Hipotek); Kreditor Konkuren (kreditor yang tidak mempunyai hak untuk didahulukan).

Berdasarkan penjabaran di atas, maka terlihat perbedaan penggolongan kreditor berdasarkan Hukum Jaminan dan Hukum Kepailitan, yang dapat disebutkan sebagai berikut: 1. Kreditor Konkuren (dalam Hukum Jaminan) tetap menjadi Kreditor Konkuren (dalam Hukum Kepailitan); 2. Kreditor Preferen (dalam Hukum Jaminan) berubah menjadi Kreditor Separatis (dalam Hukum Kepailitan); 3. Kreditor Privilege (dalam Hukum Jaminan) berubah menjadi Kreditor Preferen (dalam Hukum Kepailitan).

Perbedaan ini tidak hanya perbedaan istilah saja, melainkan ada pergeseran makna yang bermula dari pergeseran konsep. Sedasar dengan penjabaran sebelumnya, Kreditor Privilege dalam Hukum Jaminan kedudukannya lebih rendah daripada Kreditor Preferen dalam Hukum Jaminan. Sedangkan dalam Hukum Kepailitan, Kreditor Privilege dalam Hukum Jaminan kedudukannya lebih diutamakan daripada Kreditor Preferen dalam Hukum Jaminan.

Pergeseran ini makna ini mengakibatkan tidak pastinya peringkat-peringkat pelunasan kreditor dalam hal debitor diputuskan Pailit. Sebagaimana telah dijabarkan di atas, Hukum Jaminan merupakan rumah dari Hukum Kepailitan, dan Hukum Kepailitan merupakan pelaksanaan atau pengejewantahan dari Hukum Jaminan (Pasal 1131 dan 1132 BW). Manakala kedudukan kreditornya dalam Hukum 
Kepailitan telah mengalami pergeseran makna dari Hukum Jaminan, maka harus ada salah satu hukum yang dipakai, agar Hukum Jaminan dan Hukum Kepailitan dapat berjalan dengan harmonis, akibatnya saat konsep kreditor (khususnya Kreditor Preferen dan Kreditor Privilege) masih bermakna ganda, masyarakat yang mempelajari hukum dan/atau yang tersangkut dengan permasalahan tertentu, cenderung tidak dapat memahami dan/atau mendapatkan kepastian hukum yang tepat.

Penyelesaian pemaknaan kreditor sebagaimana di atas, sebenarnya dapat diselesaikan dengan menggunakan asas Lex Specialis. Kendati demikian, apabila kerancuan ini diselesaikan dengan menggunakan asas Lex Specialis, maka pengaruhnya akan besar, karena pasti yang dipakai adalah Hukum Kepailitan, namun dalam prakteknya Hukum Jaminan cenderung lebih banyak dipakai daripada Hukum Kepailitan. Hukum Jaminan pada prakteknya lebih dapat digunakan di semua jenis utang-piutang baik yang jumlahnya besar dan/atau kecil. Sedangkan Hukum Kepailitan dalam prakteknya lebih cenderung dipakai untuk perkara-perkara dengan jumlah utang yang sangat besar.

Penyelesaian yang terbaik, adalah dengan mengembalikan kedudukan kreditor pada aturanaturan Hukum Jaminan sebagai induk Hukum Kepailitan. Cara penyelesaian yang lain dapat dilakukan dengan cara apabila perkaranya adalah Hukum Kepailitan, maka pemaknaan kreditor sesuai apa yang diatur dalam UU KPKPU. Sedangkan dalam perkara Hukum Jaminan, pemaknaan kreditor akan sesuai dengan apa yang diatur dalam BW. Penyelesaian dengan metode yang terakhir ini tetap bukan merupakan penyelesaian yang sesuai dengan citra hukum yang terunifikasi, karena bukan hal yang tidak mungkin dari perkara Hukum Jaminan, akan berujung pada perkara Hukum Kepailitan, dan saat adanya perpindahan ini, maka Kreditor Preferen (dalam Hukum Jaminan) harus memahami lagi posisinya yang baru sebagai Kreditor Separatis (dalam Hukum Kepailitan), selain itu kreditor tersebut juga harus memahami kedudukannya yang tidak lagi diutamakan, namun yang diutamakan adalah Kreditor Privilege dalam Hukum Jaminan atau Kreditor Preferen dalam Hukum Kepailitan.

\section{Batasan Kreditor Separatis dalam Perkara Kepailitan}

Kreditor Separatis sebagai pemegang hak jaminan kebendaan, sebagaimana telah dijelaskan sebelumnya, adalah kreditor yang dapat mengeksekusi objek jaminan yang dijaminkan kepadanya, seolah-olah tidak terjadi Kepailitan. Pada dasarnya hal ini telah memberikan suatu keistimewaan tersendiri kepada Kreditor Separatis, agar tidak terpengaruh adanya Kepailitan pada diri debitor. Kendati demikian, dengan telah diberikannya suatu keistimewaan ini, Kreditor Separatis dapat mengajukan permohonan pailit untuk debitornya. Pengaturannya terletak dalam Pasal 2 ayat (1) UU KPKPU yang menegaskan: Debitor yang mempunyai dua atau lebih kreditor, dan tidak membayar lunas sedikitnya satu utang yang telah jatuh waktu dan dapat ditagih, dinyatakan pailit dengan Putusan Pengadilan, baik atas permohonannya sendiri, maupun atas permohonan satu atau lebih kreditornya.

Penjelasan Pasal 2 ayat (1) UU KPKPU menjelaskan bahwa: Yang dimaksud dengan Kreditor dalam ayat ini adalah baik kreditor konkuren, kreditor separatis maupun kreditor preferen. Khusus mengenai kreditor separatis dan kreditor preferen, mereka dapat mengajukan permohonan pernyataan pailit tanpa kehilangan hak agunan atas kebendaan yang mereka miliki terhadap harta Debitor dan haknya untuk didahulukan.

Dari pengaturan di atas, terbukti bahwa Kreditor Separatis selain dapat keistimewaan tersendiri dalam hal eksekusi saat debitornya dipailitkan, Kreditor Separatis juga dapat mengajukan permohonan pailit kepada debitornya.

Separatis ini artinya diberikan keleluasaan yang sangat istimewa kepada kreditor pemegang jaminan kebendaan, meskipun dalam keadaan debitor diputuskan pailit. Meuwissen berpendapat bahwa:23 Asal muasal kata "separatis" itu berkonotasi "pemisahan", karena kedudukan kreditor tersebut memang dipisahkan dari kreditor lainnya, dalam arti kreditor dapat menjual sendiri dan mengambil sendiri dari hasil penjualan, yang terpisah dengan harta pailit pada umumnya.

Pendapat Meuwissen tersebut senada dengan apa yang diungkapkan oleh Elijana bahwa kreditor separatis adalah kreditor yang tidak terkena akibat kepailitan, juga tidak berakibat pada eksekusinya

\footnotetext{
${ }^{23}$ Meuwissen, "Teori Hukum”, Majalah Hukum Pro Justitia, Tahun XII, Nomor 2 April 1994, 1994, h. 24.
} 
meskipun debitornya dinyatakan pailit. ${ }^{24}$ Munir Fuady menyebutkan bahwa kreditor separatis adalah kreditor yang memiliki jaminan hutang kebendaan (Hak Jaminan) seperti pemegang Hak Tanggungan, hipotek, Gadai, Fidusia, dan lain-lain (Pasal 55 UU KPKPU). Kreditor dengan jaminan yang bukan jaminan kebendaan yang seperti garansi termasuk garansi bank bukan merupakan kreditor separatis. Pemahaman yang dimaksudkan dengan hak kreditor separatis adalah hak yang diberikan oleh hukum kepada kreditor pemegang hak jaminan untuk tetap dapat melaksanakan hak-hak eksekusinya meskipun debitor telah dinyatakan pailit. ${ }^{25}$ Terhadap pendapat Munir Fuady tersebut, Setiawan melengkapinya dengan menjabarkan: ${ }^{26}$ Hak separatis adalah hak yang diberikan oleh hukum kepada kreditor pemegang hak jaminan, bahwa barang jaminan (agunan) yang dibebani dengan hak jaminan (hak agunan) tidak termasuk harta pailit.

Kartini Muljadi mengatakan bahwa hak penting yang dipunyai Kreditor Separatis adalah hak untuk dengan kewenangan sendiri menjual/mengeksekusi objek agunan, tanpa putusan pengadilan (parate eksekusi). Hak tersebut berlaku untuk: ${ }^{27} 1$. Gadai, di atur dalam Pasal 1155 ayat (1) BW; 2. Hipotek, di atur dalam Pasal 1178 ayat (2) BW; 3. Hak Tanggungan, di atur dalam Pasal 6 jo. Pasal 20 ayat (1) huruf (a) UUHT; 4. Jaminan Fidusia, diatur dalam Pasal 29 ayat (1) huruf (b) UUJF.

Ditambahkan oleh Kartini Muljadi bahwa:28 Kuasa menjual tersebut, dalam lembaga jaminan Hak Tanggungan dan Hipotek diberikan berdasarkan perjanjian pemberian agunan antara debitor dan kreditor, sedangkan dalam lembaga jaminan Gadai dan Fidusia, kuasa tersebut diberikan berdasarkan Undang-Undang.

${ }^{24}$ Elijana, Peraturan Pemerintah Pengganti UndangUndang Nomor 1 Tahun 1998 tentang Perubahan atas UndangUndang Kepailitan, Makalah Dalam Seminar UU Kepailitan, Jakarta, Juni 1998, 1998.

${ }^{25}$ Munir Fuady, Op.Cit., h.99.

${ }^{26}$ Setiawan, "Hak Tanggungan dan Masalah Eksekusinya", Varia Peradilan, Majalah Hukum Tahun XI Nomor 131, Agustus 1997, 1997.

27 Kartini Muljadi, Kreditor Preferens dan Kreditor Separatis dalam Kepailitan, Undang-Undang Kepailitan dan Perkembangannya: Prosiding Rangkaian Lokakarya Terbatas Masalah-Masalah Kepailitan dan Wawasan Hukum Bisnis Lainnya Tahun 2004, Jakarta, 26-28 Januari 2004, Pusat Pengkajian Hukum, 2005, h. 168.

${ }^{28} \mathrm{Ibid}$
Pendapat para ahli mengenai kreditor separatis tersebut di atas sesuai dengan Penjelasan Pasal 2 ayat (1) UU KPKPU yang menyebutkan Kreditor Separatis dan memperbolehkan seorang Kreditor Separatis untuk mengajukan permohonan pailit kepada debitor tanpa harus melepaskan hak agunan atas kebendaan. Hal ini tanpa lebih jelas lagi dalam Pasal 138 UU KPKPU, yaitu: Kreditor yang piutangnya diajamin dengan Gadai, jaminan Fidusia, Hak Tanggungan, Hipotek, hak agunan atas kebendaan lainnya, atau yang mempunyai hak yang diistimewakan atas suatu benda tertentu dalam harta pailit dan dapat membuktikan bahwa sebagian piutangnya tersebut kemungkinan tidak dapat dilunasi dari hasil penjualan benda yang menjadi agunan, dapat meminta diberikan hak-hak yang dimiliki kreditor konkuren atas bagian piutang tersebut, tanpa mengurangi hak untuk didahulukan atas benda yang menjadi agunan atas piutangnya.

Berdasarkan pengaturan dalam Pasal 138 UU KPKPU di atas, Jono berpendapat bahwa: ${ }^{29} \mathrm{UU}$ KPKPU memberikan hak kepada kreditor separatis dan kreditor privilege untuk dapat tampil sebagai kreditor konkuren, tanpa harus melepaskan hakhak untuk didahulukan atas benda yang menjadi obyek agunan atas piutangnya, tetapi dengan catatan bahwa kreditor separatis dan kreditor privilege dapat membuktikan bahwa benda yang menjadi agunan tersebut tidaklah cukup untuk melunasi hutangnya debitor yang pailit. Tidak cukupnya harta debitor pailit untuk melunasi utang-utangnya dari hasil penjualan benda yang menjadi agunan piutang tersebut haruslah dibuktikan. Beban pembuktian benda tersebut berada di pundak kreditor separatis atau kreditor privilege.

Pendapat Jono di atas menandakan bahwa Kreditor Separatis atau Kreditor Preferen dalam Hukum Kepailitan dapat juga tetap mendapatkan pelunasan piutangnya dan berkedudukan sebagai kreditor konkuren, bilamana memang dapat dibuktikan benda yang dijaminkan kepada kreditor tersebut tidak cukup untuk melunasi hutang mereka.

Berkaitan dengan pembagian kreditor di atas dalam peristiwa kepailitan, HMN Purwosutjipto mengatakan bahwa: ${ }^{30}$ Bagi kreditor separatis yang telah memegang jaminan akan mempunyai wewenang

${ }^{29}$ Jono, Hukum Kepailitan, Sinar Grafika, Jakarta, 2015, h. 10 .

${ }^{30}$ H.M.N Purwosutjipto, Pengertian Pokok Hukum Dagang Indonesia Jilid 8, Djambatan, Jakarta, 1992, h. 20. 
untuk melaksanakan eksekusi secara langsung tanpa memerlukan lagi izin dari ketua Pengadilan Niaga, akan tetapi jika dalam pelaksanaan eksekusi ternyata masih terdapat kekurangan pembayaran jumlah hutang, maka kreditor separatis akan berubah statusnya menjadi kreditor konkuren dalam hal pembayaran dari kekurangan hutang tersebut. Sedangkan bagi kreditor konkuren yang dalam hal ini tidak memegang jaminan apapun dari debitor pailit maka kreditor konkuren tidak mempunyai kekuatan eksekusi dan kreditor konkuren ini dalam menerima pembayaran piutangnya menunggu Putusan Ketua Pengadilan Niaga yang berwenang, untuk kemudian diadakan pelelangan secara umum.

Bertolak dari pendapat para ahli dan berbagai peraturan tentang hukum jaminan kebendaan (Gadai, Hipotek, Hak Tanggungan dan Fidusia) sebagaimana yang terurai di atas, J. Satrio menegaskan bahwa dapat dipahami yang dimaksudkan dengan hak kreditor separatis terkandung unsur-unsur sebagai berikut: ${ }^{31}$ Kreditor diberi hak secara ex lege; Hak timbul dari hak jaminan kebendaan; Kreditor memiliki hak jaminan kebendaan; Kreditor mempunyai kedudukan didahulukan dari kreditor konkuren; Debitor telah dinyatakan pailit; Kreditor tidak terkena akibat debitor pailit; Hak jaminan tidak termasuk harta pailit; Kreditor dapat melaksanakan eksekusinya terhadap benda jaminan; Kreditor mempunyai kewenangan untuk menjual sendiri dan menerima hasil penjualan yang terpisah dari harta pailit; Wilayah Pengadilan yang berwenang menerima, memeriksa, memutuskan adalah Pengadilan Niaga.

Berdasarkan penjabaran di atas, maka dari itu dengan dibolehkannya Kreditor Separatis dalam mengajukan permohonan pailit, ini sangat menimbulkan pertanyaan, karena seakan-akan Kreditor Separatis begitu berkuasa atas debitornya yang mana hanya karena hubungan perjanjian utang-piutangnya. Berkuasa disini yang dimaksud adalah Kreditor Separatis tersebut padahal tidak terkena akibat kepailitan (dapat mengeksekusi objek jaminannya seakan-akan tidak terjadi Kepailitan), namun dapat mengajukan permohonan pailit pada debitornya. Permohonan pailit yang berujung pada Putusan Pailit tentunya juga merugikan debitor, hal ini karena saat seorang diputuskan pailit, maka akibatnya adalah: ${ }^{32}$

\footnotetext{
${ }^{31}$ J. Satrio, Op.Cit., h. 284.

${ }^{32}$ Jono, Op.Cit, h. 124.
}

Seluruh kekayaan debitor tersebut, serta segala sesuatu yang diperoleh selama Kepailitan, itu berada dalam sitaan umum sejak saat Putusan Pailit diucapkan, kecuali: pertama, Benda, termasuk hewan yang benar-benar dibutuhkan oleh debitur sehubungan dengan pekerjaannya, perlengkapannya, alat-alat medis yang dipergunakan untuk kesehatan, tempat tidur, dan perlengkapannya yang dipergunakan oleh debitor dan keluarganya, dan bahan makanan untuk 30 (tiga puluh) hari bagi debitor dan keluarganya, yang terdapat di tempat itu; kedua, Segala sesuatu yang diperoleh debitor dari pekerjaannya sendiri sebagai pengajian dari suatu jabatan atau jasa, sebagai upah, pensiun, uang tunggu atau uang tunjangan, sejauh yang ditentukan oleh hakim pengawas; atau ketiga, Uang yang diberikan kepada debitor untuk memenuhi suatu kewajiban memberi nafkah menurut undang-undang.

Tanggal Putusan tersebut dihitung sejak pukul 00.00 waktu setempat. Sejak tanggal Putusan Pailit tersebut diucapkan, debitor pailit demi hukum tidak mempunyai kewenangan lagi untuk menguasai dan mengurus harta kekayaannya.

Tidak hanya debitor akan mengalami kerugian, namun kreditor lainnya juga akan menderita kerugian. Contohnya apabila terdapat Kreditor Konkuren yang masih punya piutang terhadap debitor yang dipailitkan, dan masih berpotensi mendapatkan keuntungan bunga dari piutangnya.

Pada prakteknya, perkara yang dimohonkan penyelesaian menggunakan Hukum Kepailitan, adalah perkara utang-piutang yang sangat besar, dan kerapkali terjadi hanya karena si debitor tidak mempunyai itikad baik untuk membayar utang kepada kreditor, dan oleh karenanya debitor dimohonkan pailit. Setelah semua utang berhasil dibayar dari semua harta debitor pailit yang disita, maka harta debitor yang masih tersisa akan dikembalikan kepada debitor dan berujung lepasnya debitor dari keadaan pailit. Walaupun perekonomian debitor dapat pulih kembali, namun Putusan pailit mengikat semua kreditor, artinya pada saat dipailitkannya seorang debitor, maka semua utang-utangnya harus dibayar, dan kreditor lainnya seperti Kreditor Konkuren dapat menderita kerugian atas bunga piutang yang seharusnya didapat namun tidak didapatkan karena piutang harus dilunasi atas dasar debitor yang berada dalam Putusan pailit. 
Keadaan yang dijabarkan sedemikian rupa tersebut, manakala yang memohonkan pailit adalah Kreditor Separatis yang pada dasarnya pelunasannya adalah aman dengan adanya jaminan untuk mereka (dapat langsung mengeksekusi jaminan kebendaan), maka dengan sangat terpaksa kreditor lain akan terikat Putusan pailit debitor. Keadaan demikian perlu dilakukan telaah lebih lanjut, dan sudah selayaknya Kreditor Separatis ini diberikan batasan-batasan untuk dapat mengajukan permohonan pailit. Artinya untuk kreditor pemegang jaminan kebendaan yang debitornya telah wanprestasi, manakala tidak ingin mengeksekusi jaminan kebendaan yang diberikan untuknya, dan akan memperkarakan debitor dengan memohonkan pailit si debitor, maka kreditor tersebut haruslah memenuhi syarat-syarat tertentu, selain syarat-syarat pengajuan permohonan pailit yang terdapat dalam Pasal 2 ayat (1) UU KPKPU. Penerapan syarat-syarat ini, juga memerlukan beberapa pertimbangan, antara lain adalah pertimbangan tentang dasar diberlakukannya Hukum Kepailitan.

\section{Pertimbangan dari Dasar Diberlakukannya Hukum Kepailitan}

Pada hakikatnya, kepailitan dalam UndangUndang Kepailitan hanya bertujuan untuk mempermudah mempailitkan subjek hukum, dimana syarat kepailitan hanya memiliki dua variable, yakni adanya utang yang telah jatuh tempo dan dapat ditagih kembali, serta memiliki setidak-tidaknya dua kreditor. Hukum kepailitan di Indonesia menganut prinsip utang dalam konsep luas, akan tetapi tidak menganut prinsip pembatasan jumlah nilai nominal uang seperti yang terdapat dalam sistem kepailitan di negara lain. Dijelaskan oleh Hadi Subhan sebagai berikut: ${ }^{33}$ Argumentasi yuridisnya adalah bahwa dengan tidak dibatasi jumlah minimum utang sebagai dasar pengajuan permohonan kepailitan, maka akan terjadi penyimpanan hakikat kepailitan dari kepailitan sebagai pranata likuidasi yang cepat terhadap kondisi keuangan debitor yang tidak mampu melakukan pembayaran utang-utangnya kepada para kreditor, sehingga untuk mencegah terjadinya unlawful execution dari pada kreditor menjadikan kepailitan sebagai alat tagih semata atau debt collection tool.

Berdasarkan penjelasan UU Kepailitan, beberapa faktor perlunya pengaturan mengenai kepailitan dan

\footnotetext{
${ }^{33}$ Hadi Subhan, Op.Cit., h. 93
}

penundaan kewajiban pembayaran utang adalah: ${ }^{34}$ Pertama, Menghindarkan pertentangan apabila ada beberapa kreditor pada waktu yang sama meminta pembayaran piutangnya dari debitur; Kedua, Untuk menghindari adanya kreditor yang ingin mendapatkan hak istimewa, yang menuntut haknya dengan cara menjual barang milik debitur atau menguasai sendiri secara tanpa memperhatikan lagi kepentingan debitur atau kreditor lainnya; Ketiga, Untuk menghindari adanya kecurangan-kecurangan yang dilakukan oleh debitur sendiri, misalnya saja debitur berusaha untuk memberi keuntungan kepada seorang atau beberapa kreditor tertentu, yang merugikan kreditor lainnya, atau debitur melakukan perbuatan curang dengan melarikan atau menghilangkan semua harta benda kekayaan debitur yang bertujuan melepaskan tanggung jawabnya terhadap para kreditor.

Ditambahkan oleh Jerry Hoff, bahwa suatu hukum kepailitan dapat memenuhi tujuan-tujuan di bawah ini: ${ }^{35}$

Pertama, Meningkatkan upaya pengembalian kekayaan. Semua kekayaan debitur harus ditampung dalam suatu kumpulan dana yang sama-disebut harta kepailitan-yang disediakan untuk pembayaran tuntutan kreditor. Kepailitan menyediakan suatu forum untuk likuidasi secara kolektif atas aset debitur.

Kedua, Memberikan perlakuan baik yang seimbang dan yang dapat diperkirakan sebelumnya kepada para kreditor. Pada dasarnya, para kreditor dibayar secara pari passu; mereka menerima suatu pembagian secara pro rata parte dari kumpulan dana tersebut sesuai dengan besarnya tuntutan masingmasing. Prosedur dan peraturan dasar dalam hubungan ini harus dapat memberikan suatu kepastian dan keterbukaan. Kreditor harus mengetahui sebelumnya mengenai kedudukan hukumnya.

Ketiga, Memberikan kesempatan yang praktis untuk reorganisasi perusahaan yang sakit, tetapi masih potensial bila kepentingan para kreditor dan kebutuhan sosial dilayani dengan lebih baik dengan mempertahankan debitur dalam kegiatan usahanya.

Bertolak dari penjabaran di atas, dapat ditarik suatu pengertian, bahwa dengan adanya Kepailitan ini berupa tindakan tegas berupa keputusan, yang berisi

${ }^{34}$ Fred B.G. Tumbuan, Naskah Akademik Peraturan Perundang-Undangan tentang Kepailitan, Citra Aditya Bakti, Bandung, 2002, h. 12.

35 Jerry Hoff, Undang-Undang Kepailitan Indonesia (Indonesian Bankrupcty), Tatanusa, Jakarta, 2000, h. 9-10. 
ketidakmampuan lagi seseorang untuk melakukan perbuatan hukum terkait harta kekayaannya, maka kepada seseorang tersebut semua hartanya (yang memenuhi unsur Pasal 1131 BW) yang bisa dipindahtangankan, akan disita, dan ada di bawah pengurusan Kurator dengan bantuan pengawasan dari Hakim Pengawas.

Beberapa karakter kepailitan yang mana tidak adanya jumlah minimum utang, menghindarkan pertentangan apabila ada beberapa kreditor pada waktu yang sama meminta pembayaran piutangnya dari debitor, menghindari kecurangan debitor, dan bertujuan untuk meningkatkan upaya pengembalian kekayaan, memberikan perlakuan baik yang seimbang dan yang dapat diperkirakan sebelumnya kepada para kreditor, dan memberikan kesempatan yang praktis untuk reorganisasi perusahaan yang sakit, tetapi masih potensial, menunjukkan bahwa kepailitan ini hadir untuk kepentingan bisnis, baik itu untuk kepentingan bisnis debitor dan/atau kepentingan bisnis kreditor.

Berdasarkan penjabaran di atas, dapat diketahui bahwa Kepailitan dihadirkan dan dikembangkan dalam tujuan yang baik, pada hakekatnya adalah demi kepentingan bisnis, yang artinya Hukum Kepailitan ditujukan agar kegiatan bisnis dapat terus berlangsung lancar dan payung hukum yang melindungi kegiatan bisnis tersebut (khususnya utang-piutang) dapat menyelesaikan permasalahan-permasalahan terkait pelunasan utang dengan adil, serta tidak merugikan dan/atau menambah kerugian para pihak yang berperkara, juga yang paling penting adalah untuk kepentingan seluruh kreditor. Melalui pertimbangan ini, maka sudah semestinya pengaturan-pengaturan dalam UU KPKPU tidaklah bertentangan dengan apa sebenarnya tujuan dari adanya Hukum Kepailitan.

Sebagaimana diperbolehkannya Kreditor Separatis dalam mengajukan permohonan Kepailitan, yang pada dasarnya mereka dapat langsung mengeksekusi objek jaminan yang diberikan kepadanya, juga apabila debitornya dipailitkan maka Kreditor Separatis tetap dapat mengeksekusi objek jaminan seolah tidak terjadi kepailitan. Hal ini sebagaimana dibahas di atas, cenderung mengakibatkan kerugian kepada debitor dan kreditor lainnya. Oleh karena itu pengaturan diperbolehkannya Kreditor Separatis dalam mengajukan permohonan pailit ini menyimpang dari hakekat dibentuk dan dikembangkannya Hukum Kepailitan. Atas dasar menyimpangnya aturan tersebut (Pasal 2 ayat (1) dan Penjelasan Pasal 2 ayat (1) UU KPKPU) maka beralasan apabila atas aturan tersebut harus diberikan aturan tambahan dalam pelaksanaannya.

Hak atas Kreditor Separatis sebenarnya telah terlindungi oleh jaminan yang diberikan kepadanya. Ketidakadilan dan tidak sesuainya dengan hakekat Hukum Kepailitan semakin tampak saat Kreditor Separatis diberikan hak untuk voting tanpa kehilangan hak jaminannya. Redaksi Pasal 281 UU KPKPU tampak menegaskan bahwa terlampau tinggi syarat perhitungan suara dan harus dipenuhi syarat kumulatif voting dari Kreditor Konkuren dan Kreditor Separatis, hal ini menjadi penghambat utama Penundaan Kewajiban Pembayaran Utang (PKPU) sangat terlihat sama kejamnya dengan Putusan Pailit. Oleh karenanya syarat yang dapat diterapkan antara lain adalah apabila Kreditor Separatis (yang masih memiliki objek jaminan), apabila tidak ingin menyelesaikan perkara atas tidak dibayar piutangnya tersebut dengan cara gugatan wanprestasi dan eksekusi objek jaminannya, melainkan dengan cara memohonkan pailit debitornya, maka Kreditor Separatis tersebut dalam mengajukan permohonan pailit pada debitornya, paling tidak diharuskan untuk meminta persetujuan semua pihak yang menjadi kreditor dari debitor tersebut. Manakala permohonan Kreditor Separatis tersebut disetujui oleh semua kreditor, antara lain: Kreditor Preferen, Kreditor Konkuren, dan Kreditor Separatis lainnya, maka barulah Kreditor Separatis tersebut dapat mengajukan permohonan pailit kepada debitornya, kepada Pengadilan Niaga. Sebaliknya, apabila terdapat satu kreditor yang tidak setuju, maka Kreditor Separatis tidak dapat mengajukan permohonan pailit, dan tetap dapat menyelesaikan utang-piutangnya dengan cara menggugat wanprestasi. Melalui hal ini, maka hakekat adanya Hukum Kepailitan tetap pada arah dan tujuan yang sama, yaitu demi kepentingan bisnis dan melindungi kepentingan seluruh kreditor.

Pembatasan peran Kreditor Separatis dalam kepailitan ini sebenarnya telah ada pengaturannya, namun pengaturan yang ada dalam UU KPKPU ini tidaklah membatasi Kreditor Separatis dalam mengajukan permohonan pailit, melainkan sifatnya "menakuti" Kreditor Separatis dalam bentuk setelah adanya putusan pailit pada debitor, maka Kreditor Separatis tidak dapat langsung mengeksekusi objek jaminannya, melainkan harus menunggu 90 (sembilan 
puluh) hari. Hal ini sebagaimana pengaturan Pasal 56 UU KPKPU.

\section{PENUTUP}

\section{Kesimpulan}

Hukum Kepailitan menyediakan pengaturanpengaturan penyelesaian utang-piutang, selain penyelesaian melalui wanprestasi. Keistimewaan penyelesaian utang-piutang dengan Kepailitan adalah proses persidangan hingga Putusan yang cepat, yaitu sebagaimana diatur dalam Pasal 8 ayat (4) UU KPKPU, hanya 60 (enam puluh) hari sejak diajukan permohonan. Kepailitan mengikat semua kreditor, dan yang dapat mengajukan adalah semua golongan kreditor, termasuk diantaranya adalah Kreditor Separatis, yaitu kreditor yang mempunyai jaminan kebendaan dan saat debitor diputuskan pailit, kreditor tersebut dapat mengeksekusi objek jaminan yang diberikan kepadanya, seolah-olah tidak terjadi kepailitan. Kreditor Separatis dalam memohonkan pailit atas debitornya, dinilai tidak adil dan menyimpang dari hakekat Hukum Kepailitan, karena berpotensi merugikan debitor dan kreditor lainnya (khususnya Kreditor Konkuren yang masih berpotensi mendapatkan untung dari bunga utangnya). Maka dari itu Kreditor Separatis dalam pengajuan permohonan pailit harus diberikan batasan, yaitu harus dengan persetujuan semua pihak yang menjadi kreditor (baik itu Kreditor Konkuren, Kreditor Preferen, dan Kreditor Separatis lainnya) dari debitor tersebut. Manakala terdapat satu kreditor yang tidak setuju, maka Kreditor Separatis tersebut tidak dapat memohonkan pailit, melainkan harus menyelesaikan pembayaran piutangnya dengan cara wanprestasi yang berujung pada eksekusi objek jaminannya.

\section{DAFTAR PUSTAKA}

\section{Peraturan Perundang-undangan:}

Burgerlijk Wetboek.

Undang-Undang Nomor 42 Tahun 1999 tentang Jaminan Fidusia.

Undang-Undang Nomor 4 Tahun 1996 tentang Hak

Tanggungan atas Tanah Beserta Benda-Benda yang Berkaitan dengan Tanah.

Undang-Undang Nomor 37 Tahun 2004 tentang Kepailitan dan Penundaan Kewajiban Pembayaran Utang.
Peraturan Pemerintah Pengganti Undang-Undang Nomor 1 Tahun 1998 tentang Perubahan atas Undang-Undang tentang Kepailitan.

Buku:

Meliala, Djaja S., 2007, Perkembangan Hukum Perdata tentang benda dan Hukum Perikatan, Bandung: Nuansa Alia.

Elijana, Peraturan Pemerintah Pengganti UndangUndang Nomor 1 Tahun 1998 tentang Perubahan atas Undang-Undang Kepailitan, Makalah Dalam Seminar UU Kepailitan, Jakarta, Juni 1998.

Tumbuan, Fred B.G., 2001, Pokok-Pokok UndangUndang tentang Kepailitan sebagaimana diubah oleh Perpu Nomor: 1/1998, dalam Penyelesaian Utang Piutang melalui Pailit atau penundaan Kewajiban Pembayaran Utang, Editor: Rudhi A. Lontoh, Bandung: Alumni.

Tumbuan, Fred B.G., Naskah Akademik Peraturan Perundang-Undangan tentang Kepailitan, Bandung: Citra Aditya Bakti.

Purwosutjipto, H.M.N., 1992, Pengertian Pokok Hukum Dagang Indonesia Jilid 8, Djambatan.

Subhan, Hadi, 2012, Hukum Kepailitan, Prinsip, Norma dan Praktik di Pengadilan, Jakarta: Kencana Prenadamedia.

Budiono, Herlin, 2008, Kumpulan Tulisan Hukum Perdata di Bidang Kenotariatan, Bandung: Citra Aditya Bakti.

Suci, Ivida Dewi Amrih, 2011, Hak Kreditor Separatis Dalam Mengeksekusi Benda Jaminan Milik Debitor Pailit, Yogyakarta: Laksbang Pressindo. Hoff, Jerry, 2000, Undang-Undang Kepailitan Indonesia (Indonesian Bankrupcty), Jakarta: Tatanusa.

Hoff, Jerry, 2000, Undang-Undang Kepailitan Indonesia (Indonesian Bankrupcty), Jakarta: Tatanusa.

Jono, 2015, Hukum Kepailitan, Jakarta: Sinar Grafika. Muljadi, Kartini, 2001, Kepailitan dan Penyelesaian Utang-Piutang, dalam Rudhy A. Lontoh, Penyelesaian Utang-Piutang Melalui Pailit atau Penundaan Kewajiban Pembayaran Utang, Bandung: Alumni.

Muljadi, Kartini, 2005, Kreditor Preferens dan Kreditor Separatis Dalam Kepailitan, UndangUndang Kepailitan dan Perkembangannya: Prosiding Rangkaian Lokakarya Terbatas 
Masalah-Masalah Kepailitan dan Wawasan Hukum Bisnis Lainnya Tahun 2004, Jakarta, 26-28 Januari 2004, Jakarta: Pusat Pengkajian Hukum.

Muljadi, Kartini, 2005, Prosiding Masalah-Masalah Kepailitan dari Wawasan Hukum Bisnis, Jakarta: Pusat Pengkajian Hukum.

Kartono, 1974, Kepailitan dan Pengunduran Pembayaran, Jakarta: Pradnya Paramita.

Keterangan Nindya Pramono sebagai Ahli dalam Persidangan Perkara Kepailitan No.02/Pdt.Sus PAILIT/2014/PN NIAGA MKS, di Pengadilan Niaga Makassar.

Sastrawidjaja, Man. S., 2006, Hukum Kepailitan dan Penundaan Kewajiban Pembayaran Utang, Bandung: Alumni.

Badrulzaman, Mariam Darus, 2010, Mencari Sistem Hukum Benda Nasional, Bandung: Alumni.

Fuady, Munir, 2002, Hukum Pailit dalam Teori dan Praktek, Bandung: Citra Aditya Bakti.

Subekti, R., 1981, Suatu Tinjauan tentang Sistem Hukum Jaminan Nasional, Jakarta: Binacipta.
Subekti, 2003, Pokok-Pokok Hukum Perdata, Bandung: Intermasa.

Vollmar, 1948, De Faillessementswet, Tjenk Willink \& Zoon N.V., Harlem.

\section{Jurnal:}

Meuwissen, "Teori Hukum", Majalah Hukum Pro Justitia, Tahun XII, Nomor 2 April 1994.

Setiawan, "Hak Tanggungan dan Masalah Eksekusinya", Varia Peradilan, Majalah Hukum Tahun XI Nomor 131, Agustus 1997.

Sularto, "Perlindungan Hukum Kreditor Separatis Dalam Kepailitan", Jurnal Mimbar Hukum, Volume 24 No. 2, 2012, Universitas Gajah Mada, Yogyakarta. 